\title{
The Influence of Distance from Health Facility, Family Number at Home and TB History in Starting Treatment of MDR-TB in Medan
}

\author{
R. Kintoko Rochadi ${ }^{1}$, Erna Mutiara ${ }^{2}$ \\ ${ }^{1}$ Lecturer of Department of Health Education and Behavioral Sciences, University of Sumatera Utara, Medan, \\ Sumatera Utara, 20155, Indonesia, ${ }^{2}$ Lecturer of Department of Biostatistics And Population, University of \\ Sumatera Utara, Medan, Sumatera Utara, 20155, Indonesia
}

\begin{abstract}
The national TB Program according to the long-term plan is to prevent and control of drug resistance through Management Program of MDR-TB. The objective of the program are reducing morbidity, mortality and transmission of MDR-TB. Medan is an area with the highest case of MDR-TB in Sumatera Utara Province. Until November 2018 MDR-TB case has been confirmed in the city of Medan as many as 324, which has not started the treatment are 61 patients (19\%). This research using case-control design and population is all people with MDR-TB in Medan city that recorded in E-TB Manager data. Sample case is the confirmed MDR-TB person who has not started the treatment as many as 13 people while the control is a confirmed person MDR-TB and willing to start the treatment as many as 31 people. The data is collected through interview using questionnaires and has received approval from the Ethics committee of the Faculty of Nursing University of Sumatera Utara. The data analysis is conducted with the chi-square test and the OR calculation to assess which variables affect the action of beginning MDR-TB treatment. Results showed that there was no influence of the distance of health facilities $(p=0.188)$ and family number at home ( $p=$ 0.507 ) with the status of starting treatment MDR-TB. There was influence of historical of TB with the status of starting treatment respondent MDR-TB $(p=0.021)$.
\end{abstract}

Keywords: Confirmed MDR-TB, Starting treatment, Distance of health facility, Family number at home, Historical of TB

\section{Introduction}

National TB Program in accordance with the longterm plan is to prevent and control the transmission of drug resistance through Management Program of MDRTB. In general, this program aims to reduce the number of morbidity, mortality and transmission of MDR-TB so that it is not a public health problem ${ }^{1}$.

Challenges faced in the response of MDR-TB cases from officers ie increased incidence of MDR-TB caused by low number of success of MDR-TB treatment,

\section{R. Kintoko Rochadi}

R. Kintoko Rochadi,

Email: kintokorochadi2@gmail.com,

University Street No. 21 especially in hospital health services facilities, clinics and private practitioners. Challenges for patients, families and communities, namely low understanding of MDR-TB and its dangers for patients, families and the environment so that many MDR-TB patients refuse to undergo treatment. Infectious pulmonary tuberculosis patients are potentially transmitted to 10 to 15 people annually ${ }^{2}$.

Medan is an area with the highest case of MDRTB in Sumatera Utara province. Until November 2018 MDR-TB case has been confirmed in the city of Medan as many as 324 , which has not started the treatment of 61 patients (19\%). The rest of the patients who have conducted the treatment of 282 cases $(81 \%)$, with the status in the treatment is 119 patients $(42 \%)$, more patients with no status in the treatment $(56 \%)$. For that 
it is necessary to know the factors that affect MDR-TB patients confirmed to start treatment in Medan city.

\section{Materials and Method}

This research was conducted in the city of Medan. Using the case-control study design is analyzing the factors that affect the start of treatment in TB-RO sufferers in the city of Medan. The population of all TB-RO patients and registered and has an address corresponding to the E-TB manager in the city of Medan. The case is all people with TB-RO who have not started the treatment and can be traced the address based on data in the E-TB

manager of Medan City as many as 13 people. Control is all people with MDR-TB who have started treatment and can be traced based on data in the manager of E-TB Kota Medan as many as 31 people. Collection of data using interviews using questionnaires which have been tested and approved by the Ethics Committee of the Faculty of Nursing at the University of North Sumatera. Data is analyzed with Chi-square test for category data and t-independent test for numerical data.

\section{Results and Discussion}

The Influence of Distance from Health Facility with The Starting Treatment of MDR-TB in Medan

Table 1: The Influence of Distance from Health Facility with The Starting Treatment of MDR-TB in Medan

\begin{tabular}{|l|l|l|l|l|}
\hline \multirow{2}{*}{ Variable } & \multicolumn{2}{l|}{ Treatment Status } & \multicolumn{2}{l|}{ p } \\
\cline { 2 - 5 } & \multicolumn{2}{|l|}{ Not yet started } & \multicolumn{2}{l|}{ Already started } \\
\cline { 2 - 5 } & $\mathbf{n}$ & Mean & $\mathbf{n}$ & Mean \\
\hline Distance From Health Facility & 13 & 9,38 & 31 & 12,45 \\
\hline
\end{tabular}

Based on the table above, it is obtained that the average distance of residence MDR-TB people who have not started treatment to distance from health facility $(9.38 \mathrm{~km})$ lower than those who have started treatment $(12.45 \mathrm{~km})$. Based on the test obtained the $p$-value $=$ 0.188 which means there is no influence between the distance from health facility with the status of Treatment MDR-TB. Research in line with Wulandary in Indonesia acquired value $\mathrm{P}=0,278$ which means there is no meaningful influence between the distance from health facility with health seeking for pulmonary $\mathrm{TB}^{3}$.
However, it is unlike to G, Cheng et al. in China, indicating that the distance from the health care house significantly affects the delay in drug search ${ }^{4}$. Risks factor of the TB occurrence are differs in any area due to some environmental factors ${ }^{5,8-13}$. Based on the research of Syarifah, et al in Medan, obtained the results of the inconsistency of the address of the person with TB MDR address when registering in RS, this leads to not optimizing the confirmed patients of TB MDR for treatment because the address is unclear ${ }^{9}$.

The Influence of Family Number at Home with The Starting Treatment of MDR-TB in Medan

Table 2: The Influence of Family Number at Home with The Starting Treatment of MDR-TB in Medan

\begin{tabular}{|l|l|l|l|l|l|}
\hline \multirow{2}{*}{ Variable } & \multicolumn{2}{l|}{ Treatment Status } & \multicolumn{2}{l|}{ Already Started } \\
\cline { 2 - 7 } & \multicolumn{2}{|l|}{ Not Yet Started } & Mean \\
\cline { 2 - 7 } & $\mathbf{n}$ & Mean & n & Mean \\
\hline Family number at home & 13 & 4,54 & 31 & 5,00 & 0,507 \\
\hline
\end{tabular}


According to the table above, it is known that the average number of respondents who have not started the treatment of MDR-TB (4.54) is smaller than the average number of occupants who have initiated the treatment of MDR-TB (5.00) with the $p$-value $=0.507$ means there is no influence between the family number at home with the treatment status MDR-TB

Houses that have a high density of housing will be at risk of developing TB disease because the air circulation in the housing with a high density has an effect on the moisture of the house so that the germ Tuberculosis easily develops and It is scattered in the house that is dense $^{5}$. The results of the study differ from the theory, this is because that has not started the treatment nor has started the treatment has the same average density and has an opportunity to be exposed to lung TB.

Effect Of TB History with The Starting Treatment of MDR-TB in Medan

Table 3: Effect Of TB History with The Starting Treatment of MDR-TB in Medan

\begin{tabular}{|l|l|l|l|l|l|l|l|}
\hline \multirow{2}{*}{ TB History } & \multicolumn{2}{|l|}{ Treatment Status } & \multirow{2}{*}{ P } & \multirow{2}{*}{ OR } & 95\% Cl \\
\cline { 2 - 5 } & \multicolumn{2}{|l|}{ Not Yet Started } & \multicolumn{2}{|l|}{ Already Started } & & \\
\cline { 2 - 5 } & $\mathbf{n}$ & $\mathbf{\%}$ & $\mathbf{n}$ & $\mathbf{\%}$ & \multirow{2}{*}{0,016} & \multirow{2}{*}{0,21} & \multirow{2}{*}{$0,067-0,613$} \\
\hline Already & 4 & 30,8 & 21 & 70,0 & & \\
\hline Not Ready & 9 & 69,2 & 10 & 30,0 & & \\
\hline Total & 13 & 100 & 31 & 100 & & \\
\hline
\end{tabular}

According to the table above, the proportion of respondents who have not started treatment 4 people (30.8\%) and who have a previous TB history of 21 people $(70.0 \%)$. This data shows there is a significant influence of TB history with the starting of treatment of MDR-TB patients $(\mathrm{OR}=0.21,95 \% \mathrm{CI}: 0.067-0.613)$.

Non-compliance with treatment is the main cause in treatment failures, relapse, and drug resistance research Nurwanti and Bambang in Puskesmas in the city of Semarang, obtained the $p$-value $=0,005$ in the previous treatment status variable, this means that there is an influence of previous treatment status with pulmonary TB events ${ }^{8}$. Supported by Janan Research ${ }^{7}$ in Brebes District, in the variable of the treatment history TB obtained the $p$-value $=0.02$ which means there is the influence of TB treatment history with the increase in the prevalence of TB MDR cases ${ }^{7}$. According to a latitude research done by the Mekonnen et al., against 124 respondents in West Armchiho District and Ethiopian Metema, a history of TB treatment has a significant relationship to TB MDR events with $\mathrm{OR}=7$ and $p$-value
$0,025^{5}$.

\section{Conclusion}

Results showed that there was no influence of the distance of health facilities $(p=0.188)$ and family number at home $(p=0.507)$ with the status of starting treatment MDR-TB. There was influence of historical of TB with the status of starting treatment respondent $\operatorname{MDR}-\mathrm{TB}(p=0.021)$.

Acknowledgment : Thank you to the TALENT Research Institute, University of North Sumatra for providing Research funding, with contract number: 4167/UN 5.1. R/PPM/2019 April 1, 2019

Ethical Clearance- Taken from University ethical committee

Conflict of Interest - Nil

\section{References}

1. Kementerian Kesehatan RI. Petunjuk 
Teknis Manajemen Terpadu Pengendalian Tuberklosis Resisten Obat. Direktorat Jenderal Pengendalian Penyakit dan Penyehatan Lingkungan. Jakarta. 2014.

2. Dinas Kesehatan Provinsi Sumatera Utara. Kebijakan Program Pengendalian TBC Provinsi Sumatera Utara. Medan. 2018.

3. Wulandari, L.. Peran Pengetahuan Terhadap Perilaku Pencarian Pengobatan Penderita Suspek TB Paru di Indonesia (Analisis survei pengetahuan, Sikap dan Perilaku Tuberkulosis Tahun 2010. Tesis FKM UI. 2012.

4. Cheng. G., Tolhurst. R., Li. RZ., Meng. Qy., Tang. S., Meng., et al,. Factor affecting Delay in Tuberculosis Diagnosis in Rural China: A case study in Four Countie in Shandong Province, Transaction of The Royal Society of Tropical Medicine and Hygiene. 2005; 99, 355-362 diakses dari www.elsevierhealth.com/ journal/trst

5. Departemen Kesehatan RI. Pedoman Nasional Penanggulangan tubercullosis cetakan kedua. Jakarta. 2011.

6. Mekonnen, F., Tessema, B., Moges, F., Gelaw, A., Eshetie, S., \& Kumera, G.. Multidrug resistant tuberculosis: prevalence and risk factors in districts of metema and west armachiho, Northwest Ethiopia. BMC Infectious Diseases, 2015; 15, 461. https://doi.org/10.1186/ s12879-015-1202-7

7. Janan, M.. Faktor-Faktor Risiko Yang Berhubungan Dengan Peningkatan Prevalensi Kejadian Tb Mdr Di Kabupaten Brebes Tahun 2011-2017. JKKI : Jurnal Kebijakan Kesehatan Indonesia. 2019; Vol (2) 64-70.
8. Nurwanti., Bambang, Y. Hubungan Antara Faktor Penjamu (Host) Danfaktor Lingkungan (Environment) Dengan Kejadian Tuberkulosis Paru Kambuh (Relaps)Di Puskesmas Se-Kota Semarang. Public Health Perspective Journal. 2016; Vol 1(1).

9. Syarifah., Erna, M., Sri, N. Characteristics of multidrug resistant tuberculosis (MDR-tb) patients in Medan City in 2015-2016. Indian Journal of Public Health Research \& Development. 2018; Vol 9 (8) 1541-1547. http://dx.doi.org/10.5958/09765506.2018.00957.9

10. Anwar Mallongi, Ruslan La Ane and Agus Bintara Birawida. Ecological risks of contaminated lead and the potential health risks among school children in Makassar coastal area, Indonesia. J. Environ. Sci. Technol., 2017; 10: 283-289.

11. Masriadi, Azis, R., Sumantri, E., Mallongi, A. Effectiveness of non pharmacologic therapy through surveillance approach to blood pressure degradation in primary hypertension patients, Indonesia. Indian Journal of Public Health Research and Development. vol: 9, issue : 4, 2018-04-01.

12. Sandu Siyoto, Anwar Mallongi, Muh Irfan Ilham, Syamsiar Russeng, Mustafa. Target Cancer Risks of Exposure to Carbon Monoxide and Plumbum among Attendants of Parking Lots in Panakkukang Mall and Panakkukang Square Makassar City. SRP. 2019; 10(1): 151155. doi:10.5530/srp.2019.1.28

13. Kayame, R., Mallongi, A. Relationships between smoking habits and the hypertension occurrence among the adults of communities. Indian Journal of Public Health Research and Development 2018. vol: 9. issue : 1, 2018-01-01 